DOI https://doi.org/10.30525/978-9934-26-075-9-2

\title{
CLINICAL CASE OF ACUTE MYELOBLASTIC LEUKEMIA ON THE BACKGROUND COVID-19-ASSOCIATED PNEUMONIA
}

\author{
Afanasiuk O. I. \\ Candidate of Medical Sciences, \\ Associate Professor at the Department of Internal Medicine № 3 \\ National Pirogov Memorial Medical University \\ Shmaliy V. I. \\ Candidate of Medical Sciences, \\ Associate Professor at the Department of Internal Medicine № 3 \\ National Pirogov Memorial Medical University \\ Yakovets O. O. \\ doctor-therapist of the highest category \\ Municipal non-profit enterprise \\ "Vinnytsya Clinical Multidisciplinary Hospital" of Vinnytsya City Council \\ Vinnytsya, Ukraine
}

Coronavirus is a very dangerous disease that has spread rapidly among the population of the entire planet and led to a pandemic. An important aspect of this disease is that the course is very variable and can range from mild manifestations of acute respiratory disease to extremely severe forms of acute respiratory distress syndrome with fatal outcome. It is a known fact that a more severe course of this disease is observed in older people, in the presence of concomitant pathology, such as cardiovascular disease, obesity, diabetes [1, p. 38]. An equally important feature of this disease is that the risk of COVID-19 infection is significantly higher among cancer patients than among other patients (39\% vs. $8 \%$ ) [2, p. 1]. Given the high contagiousness and the significant percentage of patients with mild course, a detailed blood test is mainly performed in patients with a confirmed diagnosis of coronavirus disease and who have a severe course, which in some categories does not allow timely diagnosis of the first manifestations of another disease, for acute respiratory disease. This also applies to oncohematological patients.

Thus, a 45-year-old patient was hospitalized in a clinic that provides care to patients with coronavirus disease. Complaints at the time of admission were general weakness, mild joint pain, dry cough, shortness of breath and fever up to $38.8^{\circ} \mathrm{C}$. History: He fell ill about 10 days ago, when there was weakness, 
cough and fever. He was treated on an outpatient basis with symptomatic drugs. The family doctor offered to take a test for covid, due to the epidemiological situation. The test was positive. An important aspect is that before the first signs of this disease, the patient considered himself completely healthy. The last scheduled examination took place about 6 months ago. No pathological changes were detected. After a few days of outpatient treatment, the patient felt shortness of breath, increased weakness. Saturation was in the range of $89-91 \%$. The patient called an ambulance, which took him to a specialized clinic. Weakened vesicular respiration was objectively determined, mainly in the lower parts of both lungs. Respiration rate -28 / min., Saturation without oxygen $89 \%$, oxygen rose to $93 \%$. X-ray revealed bilateral polysegmental pulmonary infiltration, which occupied about $30 \%$ of the lung surface. No other changes from the cardiovascular system, organs of the gastrointestinal tract were observed. In the general analysis of blood there was a slight leukopenia $\left(3.5 * 10^{9} / 1\right)$, the lower limit of platelet reference values, C-reactive protein - $115 \mathrm{~g} / \mathrm{l}$, D-dimer was increased to $850 \mathrm{ng} / \mathrm{ml}$ (reference value - less than $500 \mathrm{ng} / \mathrm{ml}$ ). Changes in blood tests were interpreted as changes that are characteristic of coronary heart disease. There were no significant changes in other results of laboratory tests of renal and hepatic function. The patient was prescribed oxygen therapy, glucocorticoids, anticoagulants and antibacterial therapy. However, in a few days the patient's condition significantly deteriorated: shortness of breath and weakness increased, chest discomfort and manifestations of hemorrhagic syndrome in the form of petechial-spotted rashes appeared. Saturation decreased to $85 \%$ on oxygen. Repeated studies revealed the following changes: increased leukopenia, thrombocytopenia, C-reactive protein to $148 \mathrm{~g} /$, D-dimer to 923 $\mathrm{ng} / \mathrm{ml}$, coagulopathy, decreased total protein and increased creatinine. The clinical and laboratory picture began to show inconsistency with coronary viral disease (increase in D-dimer on the background of coagulopathy, thrombocytopenia, which could indicate the primary manifestations of the syndrome of disseminated intravascular coagulation (DIC) and the development of polyorganism). signs of severe coronavirus disease. To assess the possibility of DIC syndrome, the patient was stratified according to the scoring system for diagnosing acute DIC and sepsis-induced coagulopathy (SIC syndrome) [3, p.762], and scored 5 points in favor of the development of DIC syndrome. Acute myeloblastic leukemia was diagnosed. An interesting fact was the situation that in the hospital the blood test was performed on the analyzer. The disadvantage of working with the analyzer is that it is impossible to count a large number of cells. This fact did not allow to diagnose the disease during hospitalization. Within a few days, the patient died of progressive 
multiorgan failure, DIC, and the development of acute respiratory distress syndrome. The final diagnosis was a combined combination of: 1) acute myeloblastic leukemia, leukemic form, hyperplastic syndrome with lung tissue damage, hemorrhagic, intoxication and immunodeficiency syndromes, rapidly progressing course. 2) Coronavirus disease with lung damage: bilateral polysegmental pneumonia in an immunodeficient patient, clinical group IV, pulmonary insufficiency III. At pathological and anatomical examination both diagnoses were verified. In $50-75 \%$ of patients with acute leukemia at diagnosis there is a fever, the risk of erroneous or untimely diagnosis increases significantly [2, p. 1]. In addition, during a coronary virus pandemic, the impression of the lungs is interpreted primarily as a manifestation of this disease. In acute leukemia, pneumonia-type lung damage is also possible, which further complicates the diagnosis of both diseases, especially in asymptomatic patients. Another important fact is that the tests are performed on an outpatient basis, mainly in severe patients and can be performed on the analyzer, the results of which may be erroneous due to the specifics of the work, which further contributes to untimely or erroneous diagnosis. Thus, this case is interesting because the patient had asymptomatic acute myeloblastic leukemia, the clinic of which manifested itself against the background of coronavirus infection, which contributed to the rapidly progressing course. Diagnosis was slowed down due to similar symptoms and the results of laboratory tests of both diseases, the inability to count a large number of formed blood elements on the analyzer, which, in turn, contributed to the incorrect interpretation of the results. Accordingly, patients with severe coronary heart disease should be sure to use the manual method of counting blood cells.

\section{References:}

1. Комісаренко С.В. Полювання вчених на коронавірус sars-cov-2, що викликає covid-19: наукові стратегії подолання пандемії. Вісн. НАН України. 2020. № 8. С. 29-71.

2. Хиць А.Р. Гострий лейкоз: рекомендації з менеджменту пацієнтів У період пандемії Український медичний часопис. 2020. 2(2) (136) - III/IV URL: https://www.umj.com.ua/article/176484/gostrij-lejkoz-rekomendatsiyiz-menedzhmentu-patsiyentiv-u-period-pandemiyi.

3. Wada H., Thachil J., Di Nisio M. і співавт. Guidance for diagnosis and treatment of disseminated intravascular coagulation from harmonization of the recommendations from three guidelines. J. Thromb. Haemost. 2013. № 11. P. 761-767. 